\title{
On the search of the ideal barrier membrane for guided bone regeneration
}

\author{
Jordi Caballé-Serrano ${ }^{1}$, Antonio Munar-Frau ${ }^{1}$, Octavi Ortiz-Puigpelat ${ }^{1}$, David Soto-Penaloza ${ }^{2}$, Miguel \\ Peñarrocha ${ }^{2}$, Federico Hernández-Alfaro ${ }^{1}$
}

\author{
${ }^{1}$ Department of Oral and Maxillofacial Surgery, School of Dentistry, Universitat Internacional de Catalunya, Barcelona, Spain \\ ${ }^{2}$ Department of Oral Surgery, School of Medicine and Dentistry, University of Valencia, Spain
}

Correspondence:

Department of Oral and Maxillofacial Surgery

School of Dentistry, Universitat Internacional de Catalunya

Barcelona, Spain

Carrer de Josep Trueta

08195 Sant Cugat del Vallès, Barcelona

jordicase@uic.es

\begin{abstract}
Caballé-Serrano J, Munar-Frau A, Ortiz-Puigpelat O, Soto-Penaloza $\mathrm{D}$, Peñarrocha $\mathrm{M}$, Hernández-Alfaro $\mathrm{F}$. On the search of the ideal barrier membrane for guided bone regeneration. J Clin Exp Dent. 2018;10(5):e477-83.

http://www.medicinaoral.com/odo/volumenes/v10i5/jcedv10i5p477.pdf
\end{abstract}

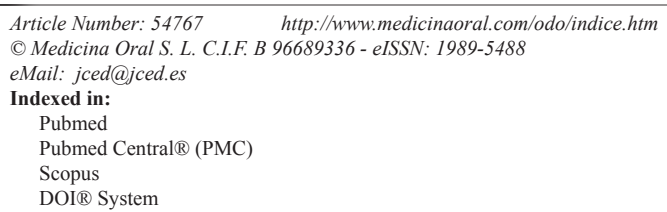

\begin{abstract}
Background: GBRs are essential procedures in implant dentistry and periodontology where barrier membranes play an important role by isolating soft tissue and allowing bone to grow. Not all membranes function the same way, as they differ from their origin and structure, it is important to understand how membranes behave and differ one from others in order to achieve a predictable treatment.

Material and Methods: A systematic search on Medline by two independent reviewers was performed for articles published until July 2017 reporting the characteristics or properties of barrier membranes. The question that preceded the search was designed according to PICO rules.

Results: A total of 124 articles were initially identified from electronic searching. After abstract/full-text review, 21 were included for a systematic review. According to the extracted data and article analysis, barrier membranes should fulfill the following criteria in order to success: biocompatibility, space maintaining, occlusive function, easy - handling and a bioactivation friendly property. With the development of new biomaterials and surfaces, a great advance in this area is expected.

Conclusions: It has been clearly described that biocompatibility is the most important requirement to take into account when choosing a membrane, but other factors such as space maintaining capacity, cell oclusiveness, easy handling and bioactivation friendly materials are the ones that will fulfill our necessities.
\end{abstract}

Key words: Barrier membrane, guided bone regeneration, dental implantology, oral surgery, collagen membrane, biomaterial. 


\section{Introduction}

Guided bone regeneration (GBR) and guided tissue regeneration (GTR) are nowadays essential procedures in implant dentistry and periodontology. Their main objective is to restore the lost tissues creating an ideal condition to place an implant or maintain a tooth. For a successful bone regeneration, the bone defect needs to be isolated from the soft tissues permitting bone to grow, taking a minimum of $4-6$ weeks for periodontal tissues and $16-24$ weeks for bone $(1,2)$. From the first GTR procedures described in the 1950s to nowadays, a need to find the ideal biomaterial for each case has existed; from a small periodontal regeneration where simple resorbable membrane are used, to vast defects where a titanium mesh should be placed $(1,3,4)$. Today, the use of a resorbable membrane is extended in the clinical practice compared to the non-resorbable membranes such as expanded polytetrafluorethylene membrane (ePTFE) $(5,6)$.

Although sometimes non-resorbable membranes are the choice of election, resorbable membrane are used in most cases due to their main advantages; similar results to non - resorbable materials, decreased morbidity, less risk of membrane exposure, no additional costs and no need of a second surgery (7). Even though resorbable membranes do not need a second surgery, they suffer from a low tensile strength which can be a limitation when compared to ePTFE membranes or a titanium mesh, lowering the ability of space maintenance (8). According to the degradation ability of membranes, newly chemically cross - linked collagen membranes have shown to present lower degradation rates. Nevertheless, having a longer resorption time does not guarantee greater bone regeneration compared to natural collagen (9).

It is important to mention that depending on the tissue origin and processing technique, the membrane will present a different degradation time and a different structure. These physical characteristics might alter the response of the evolving tissues $(10,11)$. When performing regeneration procedures we must take into account few aspects of the barrier membrane such as biocompatibility, ability to create space, cell occlusiveness, tissue integration and handling as well as the resorption time. In other words, a membrane should be stiff and biocompatible enough to avoid the soft tissue penetration or collapse into the regeneration area $(4,8)$. Numerous membranes are appearing in the market pursuing the concept of an ideal membrane that could cope with all types of regeneration. Some examples are the lately developed PLGA membranes $(2,12)$ or silk based membranes $(8)$ to new 3D (12) PLGA CAD/CAM printed materials.

The aim of this review is to reveal the ideal properties of a barrier membrane in terms of biocompatibility, occlusive properties, dimensional properties "space maintainers", handling bioactivation properties and to show what tendencies are to come in the field of membranes in bone regeneration.

\section{Material and Methods}

-Development of a protocol

A bibliographic search protocol was developed before commencing the review. This protocol included a definition of the question, a search strategy, inclusion criteria, a determination of the outcome measures, screening methods, and data analysis.

-Defining the focused question

The following issue was defined: "which main criteria should a barrier membrane fulfill"?

-Search strategy

Using the Medline PubMed database, the articles were searched including publications up to July 2017. The combinations of different terminologies were included. (Table 1).

-Criteria for study selection and inclusion

The study selection included articles published in English, describing in vitro studies, clinical trials and reviews. All studies including the guided bone regeneration (GBR) concept, excluding guided tissue regeneration. All types of membranes were included in the search.

-Outcome measure determination

The aim of this review was to assess the main criteria that a barrier membrane should fulfill, therefore looking for an ideal barrier membrane for bone regeneration.

-Screening method

Two independent reviewers (JCS and AMF) chose titles and abstracts independently. The selection was based on: "which main criteria should a barrier membrane fulfill"?. After answering this question the full text articles were obtained. Disparity regarding the inclusion criteria was resolved by a meeting between the authors.

-Data extraction and analysis

Data extraction and analysis was performed as shown in Table 1 and in Figure 1. Briefly, keywords concerning barrier membranes were selected and once having the full text of selected articles and having read them, 22 papers were selected.

\section{Results}

Barrier membranes are crucial in new bone formation. When aiming to regenerate, a resorbable or a non - resorbable membrane should be used depending on the technique and defect area (13). There has not been described the ideal membrane yet. Authors differ in their opinions; nevertheless, an ideal membrane should maintain its barrier function enough time for new bone formation, and if possible should be resorbable, so a second surgery would not be needed, thus reducing the morbidity.

Non - resorbable membranes do not suffer from a degradation process when placed in the body, but require a second surgery in order to remove them. Although e-PT- 
Table 1: Search of free text terms used for the electronic search in Medline-Pubmed.

\begin{tabular}{|c|}
\hline Search Terms \\
\hline "Membrane" OR "Barrier membrane" OR "Collagen membrane" OR "Collagen barrier membrane" \\
\hline AND \\
\hline $\begin{array}{l}\text { "Properties" OR "GBR" OR "Guided Bone Regeneration" OR "Ideal” OR "applications" OR "Natural membranes" } \\
\text { OR "Synthetic membranes" OR "oral regeneration" }\end{array}$ \\
\hline
\end{tabular}

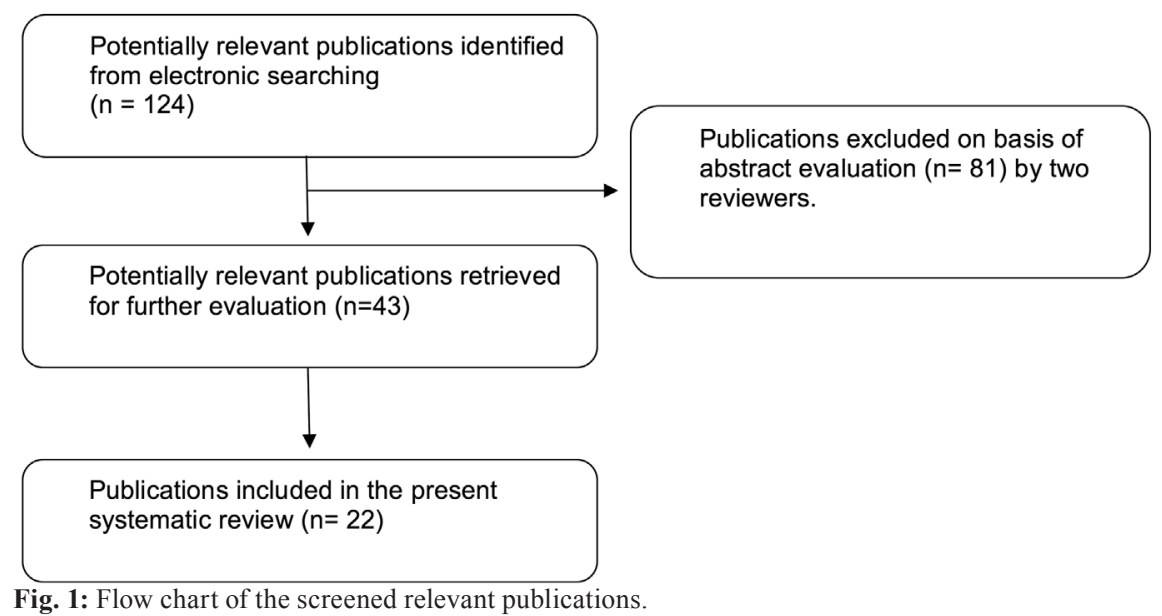

FE has been considered the gold standard membrane for GBR and GTR due to its stability and biological resistance, the inconvenient of a second surgery, and high membrane exposure rate, induced resorbable membranes to appear. On the other hand they do not suffer from a degradation process, making them one of the main membranes we must compare to (13).

In 1992 Scantlebury described five main criteria that membrane should fulfill which are: biocompatibility, the ability to create space, cell occlusiviness, tissue integration and easy - handeling (4). Therefore, an ideal bone regeneration membrane should be synthetic, biocompatible, easy to handle and resorbable (2). The morphological structure, biological stability and the ability to activate grow factors are also key factors we must take into account to gain a major bone volume.

The five main criteria that a membrane should fulfill are the following:

1. Biocompatible: the interaction between the membrane and the tissues must affect positively the surrounding tissues, leading to the healing of the defect. If the membrane is resorbable, should either degrade or integrate into the host tissues, decreasing the incompatibility that a cross - linking membrane can cause $(2,12,14-16)$.

2. Space maintainer: a membrane must be stable enough and create space to facilitate bone formation (12).

3. Occlusive: to prevent the ingrowth of soft tissues into the regeneration site but at the same time allow oxygen, fluids and bioactive substances for cell growth to reach the defect (16).

4. Easy - handling: a membrane should not be too stiff because it would not integrate with the tissue or could create dehiscence of the soft tissues; or too malleable making it difficult to work with (12).

5. Bioactivation friendly: this feature of membranes is nowadays not into consideration. However, new strategies for bone regeneration are being developed which bring the membranes into the next level, not only having a passive role but an active role into the regeneration site (2).

Graphically, these results can be displayed in a pyramid as shown in Figure 2. Publications included in the review are summarized in Table 2.

\section{Discussion}

The aim of this review was to analyze the main criteria that a barrier membrane should fulfill, to establish the ideal properties of barrier membrane as well as to analyze the tendencies when talking about GBR, on the search of the ideal membrane. Non - resorbable membranes have been widely used for decades due to their ability of long term space maintenance, from the treatment of critical size osseous defects to socket grafting, demonstrating that GBR can lead to a successful regeneration (13).

When comparing the degradation properties, according to the companies given information, porcine natural co- 


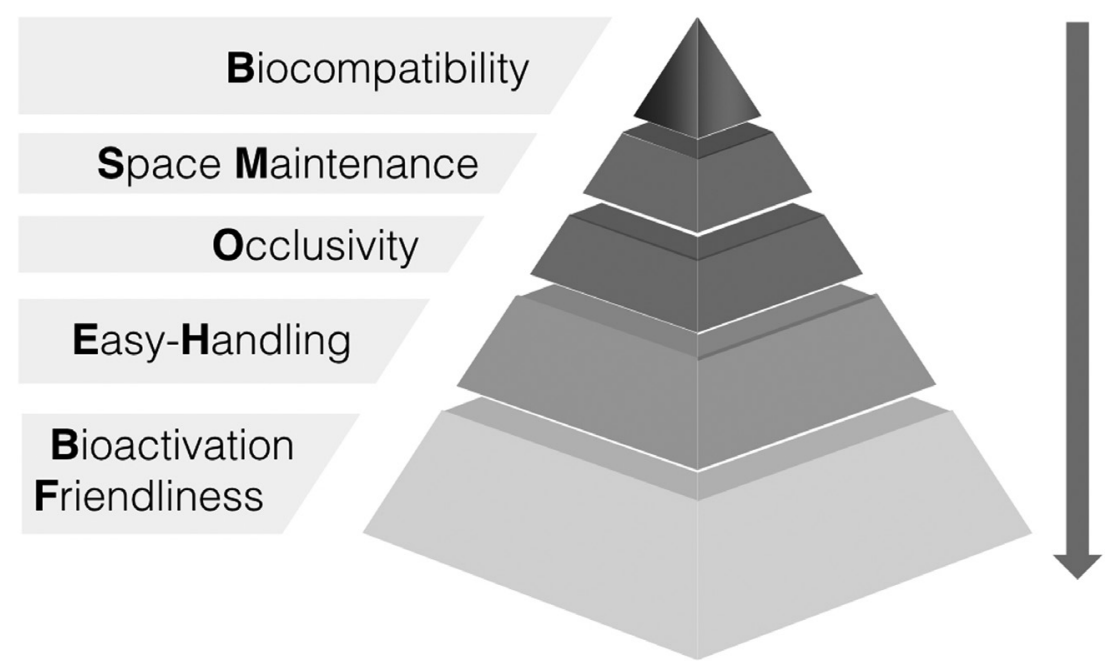

Fig. 2: Pyramid with the 5 main criteria that barrier membranes should fulfill.

llagen membranes are the fastest to resorb ( $4-8$ weeks), whereas cross-linked membranes and bone lamina membranes offer more margins in terms of resorption (4-6 months and 5-8 months respectively) (2). Apart from the surgical technique used, and as previously said, the properties of a membrane are crucial to reach the needed regeneration. As described by Scantlebury in 1992 a barrier membrane must fulfill five main criteria: biocompatibility, the ability to create space, cell occlusiviness, tissue integration and easy - handeling (4).

Lately PLGA membranes have been appearing. Biodegradable synthetic barrier PLGA membranes consist in a 2 layers membrane; a thin dense film to prevent the invasion of soft connective tissue cells, and a thick micro - fibrous layer that induces the stabilization of the blood clot allowing bony cells to colonize the membrane. PLGA membrane might be a safer and more predictable alternative for GBR due to its biocompatibility and abilities to differentiate soft tissues and maintaining its barrier function for an estimated time of 16 weeks. PLGA membranes turn to be stable as they maintain their weight for 12 weeks before beginning to lose it. Its $\mathrm{pH}$ remains stable for 12 weeks in vitro. When implanted in rats, after 26 weeks almost any part of a membrane could be seen, so it seems to be a good correlation between the in vitro and in vivo study. According to the inflammation cells less macrophages and multi - nucleated giant cells appeared in contact with the membrane, indicating its biocompatibility and use for GBR (2).

In the last years there has been a willing to improve the existing membranes or prefabricated membranes in order to achieve a better biocompatibility, and a greater capacity to form new bone, which should be one of the main standards when choosing a membrane (15). When pre - coating membranes to potentiate the activity of cells $(1,3)$, a collagen membrane would be ideal to pre - coat due to their ability to adsorb the TGF - $\beta$. Moreover, collagen membranes are a safer option in dehiscence defects making them nowadays suitable for almost any regeneration procedure (9). It is also possible to produce modified membranes using chitosan, collagen or beta-tricalcium phosphate improving some of the properties of membranes. Chitosan coated with collagen nanofibers is useful as a natural biocomposite polymer for GBR purposes and has the capacity to accelerate bone formation, considered with the biocompatibility one of the major objectives in $\operatorname{GBR}(17,18)$.

From now on, researchers are looking for other materials that can allow surface modification, such as silk membranes modified by calcium phosphate. In this case no inflammatory changes were shown and new bone formation advancing from the periphery could be detected. Due to its high biocompatibility, silk - based membranes offer an interesting alternative (19). According to Sang - woon Lee in its 2014 study, silk used in the oral cavity if well prepared by an acid treatment can be used as a barrier membrane for GBR, being its action the same as a collagen membrane, showing a small inflammatory reaction and new bone formation, being a good candidate as a drug carrier. Therefore, the proper development of this material is essential due to its properties and low price (8).

In the last years with the introduction of the $\mathrm{CAD} / \mathrm{CAM}$ systems and complemented with CBCT scans, there has been a willing to develop 3D printed membranes. In the study of J - Y won 2016, they used a 3D - printed PCL/ PLGA/ B- TCP membrane which showed comparable results to collagen membranes; therefore this new $3 \mathrm{D}$ - printed system might become an alternative to other membranes when either a GBR or GTR is required (12). 
Table 2: Summary of data extracted from publications included in the review. Authors, journal of publication, study design, membranes tested, main objective and results relevant for the review are included.

\begin{tabular}{|c|c|c|c|c|c|}
\hline Authors & Journal & $\begin{array}{l}\text { Study } \\
\text { design }\end{array}$ & Membranes tested & Main objective & Results relevant for the review \\
\hline $\begin{array}{l}\text { Caballé-Serrano } \\
\text { et al. } 2016\end{array}$ & $\begin{array}{l}\text { Clin Oral } \\
\text { Implants } \\
\text { Res }\end{array}$ & $\begin{array}{l}\text { In vitro } \\
\text { study }\end{array}$ & $\begin{array}{l}\text { Non-cross-link } \\
\text { collagen membrane }\end{array}$ & $\begin{array}{c}\text { Test bioactivation } \\
\text { capacity of membranes }\end{array}$ & $\begin{array}{l}\text { Collagen membranes can be } \\
\text { bioactivated by growth factors } \\
\text { released from autogenous bone } \\
\text { chips }\end{array}$ \\
\hline $\begin{array}{l}\text { Hornaert et al. } \\
2016\end{array}$ & $\begin{array}{l}\text { Biomed } \\
\text { Mater }\end{array}$ & $\begin{array}{l}\text { In vitro and } \\
\text { in vivo study }\end{array}$ & PLGA & $\begin{array}{c}\text { Analyze the } \\
\text { biocompatibility, } \\
\text { resorption and } \\
\text { bioactivation capacity of a } \\
\text { new synthetic } \\
\text { biodegradable membrane }\end{array}$ & $\begin{array}{l}\text { PLGA membranes are } \\
\text { biocompatible, have a controlled } \\
\text { resorption and have great } \\
\text { regeneration capacity }\end{array}$ \\
\hline $\begin{array}{l}\text { Fujioka- } \\
\text { kobayashi et al. } \\
2016\end{array}$ & $\begin{array}{l}\text { BMC Oral } \\
\text { Health }\end{array}$ & $\begin{array}{l}\text { In vitro } \\
\text { study }\end{array}$ & $\begin{array}{l}\text { Non-cross-link } \\
\text { collagen membrane }\end{array}$ & $\begin{array}{l}\text { Study how bioactivation } \\
\text { of membranes can affect } \\
\text { cell behavior positively }\end{array}$ & $\begin{array}{l}\text { Bioativation of membranes } \\
\text { increases cell attachment }\end{array}$ \\
\hline $\begin{array}{l}\text { Rakhmatia et al. } \\
2013\end{array}$ & $\begin{array}{l}\text { J } \\
\text { Prosthodont } \\
\text { Res }\end{array}$ & Review & $\begin{array}{c}\text { Resorbable } \\
\text { membranes, non- } \\
\text { resorbable } \\
\text { membranes, e- } \\
\text { PTFE membrnes } \\
\text { and Titanium mesh }\end{array}$ & $\begin{array}{l}\text { Discussion of GBR } \\
\text { principles, types of barrier } \\
\text { membranes and their } \\
\text { properties according to } \\
\text { their resorption }\end{array}$ & $\begin{array}{l}\text { An adequate selection of the barrier } \\
\text { membrane in terms of degradation } \\
\text { and biocompatibility are essential } \\
\text { for the clinical practice }\end{array}$ \\
\hline $\begin{array}{l}\text { Kaushal et al. } \\
2016\end{array}$ & $\begin{array}{l}\text { J Oral Biol } \\
\text { Craniofacial } \\
\text { Res }\end{array}$ & $\begin{array}{l}\text { Randomized } \\
\text { Clinical trial }\end{array}$ & $\begin{array}{l}\text { d-PTFE and } \\
\text { FDDMA }\end{array}$ & $\begin{array}{l}\text { Compare non-resorbable } \\
\text { barrier membranes with } \\
\text { resorbable barrier } \\
\text { membranes when used in } \\
\text { guided tissue } \\
\text { regenerations. }\end{array}$ & $\begin{array}{l}\text { Both non-resorbable and resorbable } \\
\text { membranes were equally effective } \\
\text { in terms of biocompatibility and } \\
\text { occlusivity }\end{array}$ \\
\hline $\begin{array}{l}\text { Zitzmann et al. } \\
1997\end{array}$ & $\begin{array}{l}\text { Int J Oral } \\
\text { Maxillofac } \\
\text { Implants }\end{array}$ & $\begin{array}{l}\text { Randomized } \\
\text { Clinical trial }\end{array}$ & $\begin{array}{c}\text { Resorbable } \\
\text { collagen membrane } \\
\text { and e-PTFE }\end{array}$ & $\begin{array}{l}\text { Comparison between a } \\
\text { resorbable collagen } \\
\text { membrane and an } \\
\text { expanded } \\
\text { polytetrafluoroethylene } \\
\text { membrane in GBR }\end{array}$ & $\begin{array}{l}\text { The resorbable membrane can be a } \\
\text { useful alternative due to their } \\
\text { biocompatibility, space } \\
\text { maintenance capacity, occlusivity } \\
\text { and no need for a second surgery. }\end{array}$ \\
\hline $\begin{array}{l}\text { Arx T Von et al. } \\
2005\end{array}$ & $\begin{array}{l}\text { Int J Oral } \\
\text { Maxillofac } \\
\text { Implants }\end{array}$ & $\begin{array}{l}\text { In vivo } \\
\text { study }\end{array}$ & $\begin{array}{l}\text { Collagen prototype } \\
\text { memberane, } \\
\text { reservable collagen } \\
\text { membrane, } \\
\text { glycoside-lactide- } \\
\text { trimethylene } \\
\text { carbonate } \\
\text { osseoquest } \\
\text { membrane and } \\
\text { polylactid atrisorb } \\
\text { membrane }\end{array}$ & $\begin{array}{l}\text { Barrier durability and host } \\
\text { tissue response evaluation } \\
\text { of a new prototype } \\
\text { collagen membrane }\end{array}$ & $\begin{array}{c}\text { Biocompatibility and degradation } \\
\text { of barrier membranes depend on } \\
\text { their composition and } \\
\text { physical/chemical properties. }\end{array}$ \\
\hline $\begin{array}{l}\text { Wessing et al. } \\
2016\end{array}$ & $\begin{array}{l}\text { Clin Oral } \\
\text { implants } \\
\text { Res }\end{array}$ & $\begin{array}{l}\text { Randomized } \\
\text { clinical trial }\end{array}$ & $\begin{array}{c}\text { Collagen } \\
\text { membranes }\end{array}$ & $\begin{array}{l}\text { Compare clinical } \\
\text { performance of two non- } \\
\text { cross-linked collagen } \\
\text { membranes for GBR }\end{array}$ & $\begin{array}{c}\text { Both collagen membranes are able } \\
\text { to maintain the space and facilitate } \\
\text { bone gain }\end{array}$ \\
\hline $\begin{array}{l}\text { Rothamel et al. } \\
2012\end{array}$ & $\begin{array}{l}\text { Int J Oral } \\
\text { Maxillofac } \\
\text { Implants }\end{array}$ & $\begin{array}{l}\text { In vitro and } \\
\text { in vivo study }\end{array}$ & $\begin{array}{l}\text { Collagen } \\
\text { membranes }\end{array}$ & $\begin{array}{l}\text { Examine, in vitro and in } \\
\text { vivo, a novel native } \\
\text { collagen membrane } \\
\text { extracted from porcine } \\
\text { pericardium }\end{array}$ & $\begin{array}{l}\text { The examined membranes indicate } \\
\text { a high level of biocompatibility }\end{array}$ \\
\hline $\begin{array}{l}\text { Barbeck et al. } \\
2015\end{array}$ & $\begin{array}{c}\text { J Oral } \\
\text { implantol }\end{array}$ & $\begin{array}{l}\text { In vivo } \\
\text { study }\end{array}$ & $\begin{array}{c}\text { Collagen } \\
\text { membranes }\end{array}$ & $\begin{array}{l}\text { Investigate the cellular } \\
\text { response of a dermis- } \\
\text { based collagen membrane }\end{array}$ & $\begin{array}{l}\text { Structure and composition of } \\
\text { dermis-based collagen membranes } \\
\text { can affect their biocompatibility } \\
\text { and clinical behavior }\end{array}$ \\
\hline
\end{tabular}


Table 2 continue: Summary of data extracted from publications included in the review. Authors, journal of publication, study design, membranes tested, main objective and results relevant for the review are included.

\begin{tabular}{|c|c|c|c|c|c|}
\hline Won et al. 2016 & $\begin{array}{l}\text { Biomed } \\
\text { Mater }\end{array}$ & $\begin{array}{l}\text { In vivo } \\
\text { study }\end{array}$ & $\begin{array}{c}\text { 3D-printed } \\
\text { polycaprolactone, } \\
\text { poly(lactic-co- } \\
\text { glycolic acid) and } \\
\beta \text {-tricalcium } \\
\text { phosphate } \\
\text { membranes }\end{array}$ & $\begin{array}{l}\text { Evaluate the bone } \\
\text { regeneration ability of an } \\
\text { aloplastic membrane }\end{array}$ & $\begin{array}{c}\text { The current aloplastic membrane is } \\
\text { biocompatible, can be customized } \\
\text { and be bioactivated }\end{array}$ \\
\hline Park et al. 2015 & $\begin{array}{l}\text { Biomater } \\
\text { Res }\end{array}$ & $\begin{array}{l}\text { In vitro and } \\
\text { in vivo study }\end{array}$ & $\begin{array}{l}\text { 1-ethyl-3-(3- } \\
\text { dimethylaminoprop } \\
\text { yl) carbodiimide } \\
\text { (EDC)-cross-linked } \\
\text { type I collagen } \\
\text { membrane }\end{array}$ & $\begin{array}{l}\text { Evaluation of the efficacy, } \\
\text { biocompatibility and } \\
\text { degradation of a cross- } \\
\text { linked collagen barrier } \\
\text { membrane }\end{array}$ & $\begin{array}{l}\text { The membrane tested is } \\
\text { biocompatible with adequate tissue } \\
\text { integration and resorption kinetics. }\end{array}$ \\
\hline Kim et al. 2016 & In Vivo & $\begin{array}{l}\text { In vivo } \\
\text { study }\end{array}$ & $\begin{array}{c}\text { Self made } \\
\text { PHEMA-PMMA } \\
\text { barrier membrane }\end{array}$ & $\begin{array}{c}\text { Test the GBR capacity of } \\
\text { a PHEMA-PMMA } \\
\text { membrane }\end{array}$ & $\begin{array}{l}\text { PHEMA-PMMA membranes could } \\
\text { provide an effective environment } \\
\text { for bone healing due to its } \\
\text { biocompatibility and occlusivity }\end{array}$ \\
\hline $\begin{array}{l}\text { Hämmerle et al. } \\
2003\end{array}$ & $\begin{array}{l}\text { Periodontol } \\
2000\end{array}$ & Review & $\begin{array}{l}\text { e-PTFE, Titanium } \\
\text { reinforced e-PTFE } \\
\text { and reservable } \\
\text { membranes }\end{array}$ & $\begin{array}{l}\text { Review of the techniques } \\
\text { and membrane materials } \\
\text { used for GBR }\end{array}$ & $\begin{array}{c}\text { Biocompatibility, space } \\
\text { maintenance, occlusivity and } \\
\text { handling of barrier membranes are } \\
\text { important aspects to take into } \\
\text { account when performing a GBR. }\end{array}$ \\
\hline Lee et al. 2012 & $\begin{array}{l}\text { J Biomed } \\
\text { Mater Res } \\
\text { B Appl } \\
\text { Biomater }\end{array}$ & $\begin{array}{l}\text { In vitro } \\
\text { study }\end{array}$ & $\begin{array}{l}\text { Collagen } \\
\text { composite } \\
\text { membranes } \\
\text { reinforced by } \\
\text { chitosan and b- } \\
\text { tricalcium } \\
\text { phosphate } \\
\end{array}$ & $\begin{array}{l}\text { Evaluation of different } \\
\text { concentrations of chitosan } \\
\text { and b-tricalcium } \\
\text { phosphate }\end{array}$ & $\begin{array}{l}\text { The tested membranes are good } \\
\text { candidates for GBR as they possess } \\
\text { good biocompatibility }\end{array}$ \\
\hline Loft et al. 2016 & $\begin{array}{c}\text { Ann } \\
\text { Biomed Eng }\end{array}$ & $\begin{array}{l}\text { In vitro and } \\
\text { in vivo study }\end{array}$ & $\begin{array}{l}\text { Self made chitosan } \\
\text { membranes }\end{array}$ & $\begin{array}{c}\text { Evaluation of the } \\
\text { biocompatibility and } \\
\text { osteogenic differentiation } \\
\text { of MSCs on two different } \\
\text { collagenous coatings of } \\
\text { bilayered } \\
\text { collagen/chitosan } \\
\text { membrane plus a } \\
\text { histological evaluation }\end{array}$ & $\begin{array}{l}\text { The chitosan-nano electrospun } \\
\text { collagen membrane is a } \\
\text { biocompatible barrier membrane } \\
\text { that can have the potential use for } \\
\text { GBR facilitating bone formation }\end{array}$ \\
\hline $\begin{array}{l}\text { Smeets et al. } \\
2016\end{array}$ & $\begin{array}{l}\text { J Biomed } \\
\text { Mater Res } \\
\text { B Appl } \\
\text { Biomater }\end{array}$ & $\begin{array}{l}\text { In vitro and } \\
\text { in vivo study }\end{array}$ & $\begin{array}{c}\text { Modified silk- } \\
\text { based membranes }\end{array}$ & $\begin{array}{l}\text { Assess the } \\
\text { biocompatibility of novel } \\
\text { silk protein membranes } \\
\text { with and without } \\
\text { modification and evaluate } \\
\text { they effect on GBR }\end{array}$ & $\begin{array}{l}\text { The current barrier membrane } \\
\text { displays excellent biocompatibility } \\
\text { and represent an interesting new } \\
\text { alternative to collagen membranes }\end{array}$ \\
\hline Liu et al. 2011 & $\begin{array}{l}\text { Int J Oral } \\
\text { Maxillofac } \\
\text { Implants }\end{array}$ & $\begin{array}{l}\text { In vitro } \\
\text { study }\end{array}$ & $\begin{array}{l}\text { Collagen } \\
\text { membranes }\end{array}$ & $\begin{array}{l}\text { Evaluation of the } \\
\text { influence of collagen } \\
\text { membranes on the } \\
\text { proliferation of human } \\
\text { mesenchymal stem cells } \\
\text { (hMSCs) }\end{array}$ & $\begin{array}{l}\text { Porcine collagen membranes } \\
\text { showed a good biocompatibility in } \\
\text { vitro for hMSCs. }\end{array}$ \\
\hline
\end{tabular}

One thing we must consider when choosing a membrane is its morphological structure and processing. As Rothamel et al. described in their article, when comparing RPCM (Remotis Pericardium Collagen Membrane) to Bio - Gide, both membranes showed a comparable tissue integration (10). Although cross - linking increases the degradation time, it might compromise the biocompatibility of the membrane due to the crosslinking agents which produce an inflammatory response leading in some cases to a failure of the tissue integration (14).
In general, collagen membranes show good results, nevertheless there is a trend to show that cross-linked membranes are less biocompatible. In Qin Liu's study, authors showed that porcine collagen membranes had a great in vitro biocompatibility and a moderate to low cytotoxicity. Proliferation rates were adequate, but if required, a pre - washing of the membrane could reach higher proliferation rate (20).

As any material, we must take into account their properties and ideal use scenario, but we must never forget that 
when talking about surgery we should be as less invasive as possible, therefore it is important not to raise big flaps or second surgery flaps for membrane removal, lowering patients morbidity (21). This review has limitations. To perform a review to asses the state of the art of a specific topic implicates the systematic search of literature to be as evidence based as possible. Nevertheless, the present review could not be performed as a systematic review using all PRISMA guidelines due to the singularity of the present report.

\section{Conclusions}

From the first development of barrier membranes until today there has been a great development in membrane science. Although nowadays natural collagen membranes are the ones that offer the wider range indications, we must consider that they are no suitable for every procedure, and that the clinician should be aware of the situation required to choose the right membrane.

It has been clearly described that biocompatibility is the most important requirement to take into account when choosing a membrane, but other factors such as space maintaining capacity, cell oclusiveness, easy handling and bioactivation friendly materials are the ones that will fulfill our necessities.

Future studies are needed to clarify how pre - coated membranes function, to analyze new materials and new methods on making the ideal membrane for a patient. It is therefore important not to forget the main criteria that a membrane should fulfill.

\section{References}

1. Caballé-Serrano J, Sawada K, Miron RJ, Bosshardt DD, Buser D, Gruber R. Collagen barrier membranes adsorb growth factors liberated from autogenous bone chips. Clin Oral Implants Res. 2016;28:236 241.

2. Hoornaert A, Arros C, Heymann M, Layrolle P. Biocompatibility, resorption and biofunctionality of a new synthetic biodegradable membrane for guided bone regeneration. Biomed Mater. 2016;11:045012.

3. Fujioka-kobayashi M, Caballé-serrano J, Bosshardt DD, Gruber R, Buser D, Miron RJ. Bone conditioned media (BCM) improves osteoblast adhesion and differentiation on collagen barrier membranes. BMC Oral Health. 2016;17:7.

4. Rakhmatia YD, Ayukawa Y, Furuhashi A, Koyano K. Current barrier membranes: Titanium mesh and other membranes for guided bone regeneration in dental applications. J Prosthodont Res. 2013;57:3-14.

5. Kaushal S, Kumar A, Khan MA, Lal N. Comparative study of nonabsorbable and absorbable barrier membranes in periodontal osseous defects by guided tissue regeneration. J Oral Biol Craniofacial Res. 2016;6:111-7.

6. Zitzmann NU, Naef R, Schärer P. Resorbable Versus Nonresorbable Membranes in Combination With Bio-Oss for Guided Bone Regeneration. Int J Oral Maxillofac Implants. 1997;12:844-52.

7. Arx T Von, Med PD, Nina D, Dent M, Storgård S. Membrane Durability and Tissue Response of Different Bioresorbable Barrier Membranes : A Histologic Study in the Rabbit Calvarium. Int J Oral Maxi1lofac Implants. 2005;20:843-53.

8. Lee S, Kim S. Membranes for the Guided Bone Regeneration. Maxillofac Plast Reconstr Surg. 2014;36:239-246.

9. Wessing B, Urban I, Montero E, Zechner W, Hof M, Alández Chamorro J, et al. A multicenter randomized controlled clinical trial using a new resorbable non-cross-linked collagen membrane for guided bone regeneration at dehisced single implant sites: interim results of a bone augmentation procedure. Clin Oral Implants Res. 2017;28:218-226.

10. Rothamel D, Schwarz F, Fienitz T, Smeets R, Dreiseidler T, Ritter L, et al. Biocompatibility and Biodegradation of a Native Porcine Pericardium Membrane: Results of In Vitro and In Vivo Examinations. Int J Oral Maxillofac Implants. 2012;27:146-54.

11. Barbeck M, Lorenz J, Kubesch A, Böhm N, Booms P, Choukroun J, Sader R, Kirkpatrick CJ,Ghanaati S. Porcine dermis-derived collagen membranes induce implantation bed vascularization via multinucleated giant cells: A physiological reaction? J Oral Implantol. 2015;41:e238-51.

12. Won JY, Park CY, Bae JH, Ahn G, Kim C, Lim DH, Cho DW, Yun WS, Shim JH, Huh JB. Evaluation of 3D printed PCL / PLGA / $\beta$-TCP versus collagen membranes for guided bone regeneration in a beagle implant model. Biomed Mater. Biomed Mater. 2016;11:055013.

13. Retzepi M, Donos N. Guided Bone Regeneration: biological principle and therapeutic applications. Clin Oral Implants Res. 2010;21:567-76.

14. Park JY, Jung IH, Kim YK, Lim HC, Lee JS, Jung UW, et al. Guided bone regeneration using 1-ethyl-3-(3-dimethylaminopropyl) carbodiimide (EDC)-cross-linked type-I collagen membrane with biphasic calcium phosphate at rabbit calvarial defects. Biomater Res. 2015;30:19:15.

15. Kim S, Hwang Y, Kashif M, Jeong D, Kim G. Evaluation of Bone Regeneration on Polyhydroxyethyl-polymethyl Methacrylate Membrane in a Rabbit Calvarial Defect Model. In Vivo. 2016;30:587-91.

16. Hämmerle $\mathrm{CH}$, Jung RE. Bone augmentation by means of barrier membranes. Periodontol 2000. 2003;33:36-45.

17. Lee S, Kwon JS, Lee YK, Kim KM, Kim KN. Bioactivity and mechanical properties of collagen composite membranes reinforced by chitosan and $\beta$-tricalcium phosphate. J Biomed Mater Res B Appl Biomater. 2012;100:935-42.

18. Loft G, Shokrogozar MA, Mofid R, Abbas FM, Ghanavati F, Baghban AA, Yavari SK, Pajoumshariati S. Biological Evaluation (In Vitro and In Vivo) of Bilayered Collagenous Coated (Nano Electrospun and Solid Wall) Chitosan Membrane for Periodontal Guided Bone Regeneration. Ann Biomed Eng. 2016;44:2132-44.

19. Smeets R, Knabe C, Kolk A, Rheinnecker M, Gröbe A, Heiland $\mathrm{M}$, et al. Novel silk protein barrier membranes for guided bone regeneration. J Biomed Mater Res B Appl Biomater. 2017;105:2603-2611. 20. Liu Q, Humpe A, Kletsas D, Warnke F, Becker ST, Douglas T, Sivananthan S, Warken PH . Proliferation Assessment of Primary Human Mesenchymal Stem Cells on Collagen Membranes for guided bone regeneration. Int J Oral Maxillofac Implants. 2011;26:1004-10.

21. Hämmerle CH, Jung RE, Yaman D, Lang NP. Ridge augmentation by applying bioresorbable membranes and deproteinized bovine bone mineral : a report of twelve consecutive cases. Clin Oral Implants Res. 2008;19:19-25.

\section{Conflict of interest}

The authors have declared that no conflict of interest exist. 